\title{
GON4L wt Allele
}

National Cancer Institute

\section{Source}

National Cancer Institute. GON4L wt Allele. NCI Thesaurus. Code C132121.

Human GON4L wild-type allele is located in the vicinity of $1 \mathrm{q} 22$ and is approximately 110 $\mathrm{kb}$ in length. This allele, which encodes GON-4-like protein, is involved in transcriptional repression. 